\title{
Basal Cell Adenocarcinoma of the Parotid Gland with Rare Scalp Metastasis: A Case Report
}

\author{
Skalpte Nadir Görülen Parotis Bezi Bazal Hücreli Adenokarsinom \\ Metastaz:: Olgu Sunumu
}

\author{
Ahmet EROGLU1 ${ }^{1}$, Ferhat CUCE², Hakan $\mathrm{SIMSEK}^{3}$, Ali Kıvanc TOPUZ ${ }^{4}$, Bulent DUZ ${ }^{3}$ \\ ${ }^{1}$ Van Military Hospital, Clinic of Neurosurgery, Van, Turkey \\ ${ }^{2}$ Van Military Hospital, Department of Radiology, Van, Turkey \\ ${ }^{3}$ GATA Haydarpasa Training Hospital, Department of Neurosurgery, Istanbul, Turkey \\ ${ }^{4}$ Kasımpasa Military Hospital, Department of Neurosurgery, Istanbul, Turkey
}

Corresponding Author: Ahmet EROGLU / E-mail: drahmeteroglu@gmail.com

\begin{abstract}
Salivary gland tumors constitute $3 \%$ of tumors in the body. Salivary gland tumors constitute $4 \%$ to $10.80 \%$ of all tumors in the head and neck tumors and most of them originate from the parotid gland. Most salivary gland tumors are benign. Basal cell adenocarcinoma is a rare salivary gland tumour. Most appear to be benign clinically. Metastases have occurred in less than $10 \%$ of patients. A 58 -year-old female patient was admitted with the complaint of a growing mass at the top of her head. She was operated for parotid adenocarcinoma two years ago. Computed Tomography (CT) was performed to clarify the relationship between the mass with the calvarium and intracranial region. There is a risk of malignancy in scalp and calvarium lesions. Patients must be subjected to preoperative radiological evaluations.
\end{abstract}

KEYWORDS: Basal cell adenocarcinoma, Scalp, Parotid gland

öz

Tükürük bezi tümörleri vücutta görülen tümörlerin \%3'ünü, baş ve boyun bölgesindeki tümörlerin ise \%4-10.80'ini oluşturmaktadır. Tükürük bezi kökenli bütün tümörlerin \%80'i parotis bezi kökenlidir. Tükürük bezi tümörlerinin çoğu benign karakterdedir. Bazal hücreli adenokarsinom nadir görülen bir tükürük bezi tümörüdür. Olguların \%10'undan daha azında metastaz görülür. 58 yaşında kadın hasta kafasında şişlik şikayeti ile kliniğimize başvurdu. Hastanın hikayesinden yaklaşık 2 yıl önce parotis bezi adenokarsinomu nedeni ile opere edildiği öğrenildi. Skalpteki lezyon ile intrakranial bölge arasındaki ilişkiyi net olarak ortaya koymak için hastaya bilgisayarlı tomografi (BT) tetkiki yapıldı.

Skalp ve kalvarial lezyonlarda malignite riski vardır. Preoperatif dönemde radyolojik değerlendirmeler mutlaka yapılmalıdır.

ANAHTAR SÖZCÜKLER: Bazal hücreli adenokarsinom, Skalp, Parotis bezi

\section{INTRODUCTION}

Basal cell adenocarcinoma (BCA) of the salivary gland is a rare entity that was first described as a malignant salivary gland tumor in 1970 (6). BCA accounts for approximately 1\% to $2 \%$ of all salivary gland tumors(7). Scalp metastasis of BCA has not been reported in the literature.

\section{CASE REPORT}

A 58-year-old female patient was admitted with a complaint of a growing mass with tenderness at the top of her head. The patient had been operated for basal cell adenocarcinoma of the left parotid gland three times previously. Physical examination revealed a $3 \times 2 \mathrm{~cm}$, round, hard, fixed, painful mass at the upper left parietal region. She had left facial nerve palsy from the total parotidectomy (Figure 1). Cervical lymph nodes were not palpable and other neurological examination findings were normal. Routine blood tests were normal. Ultrasound study revealed vascular structures in this irregular solid lesion. Because of the previous history of malignancy, computed tomography (CT) was performed to clarify the relationship between the mass and the head and neck. CT demonstrated two adjacent solid lesions located in the subgaleal region (Figure 2). The larger one was $2.5 \times 2 \times 1,5 \mathrm{~cm}$ in size. The parietal bone adjacent to the lesions and the other calvarial bones were normal. On contrast-enhanced CT images, the lesions showed significant enhancement suggesting increased vascularity. There were also postoperative changes in the left parotid region but no evidence of tumor recurrence. Excisional biopsy was planned for the differential diagnosis and the subgaleal masses were excised totally (Figure 3). The histopathology result was reported as metastasis of parotid gland basal cell adenocarcinoma (Figure 4, 5). There was no postoperative complication and no tumor recurrence in any localization for one-year follow-up.

\section{DISCUSSION}

BCA appears most frequently in the parotid gland and in adults $(4,5)$. It is an infiltrative and local destructive tumor and 


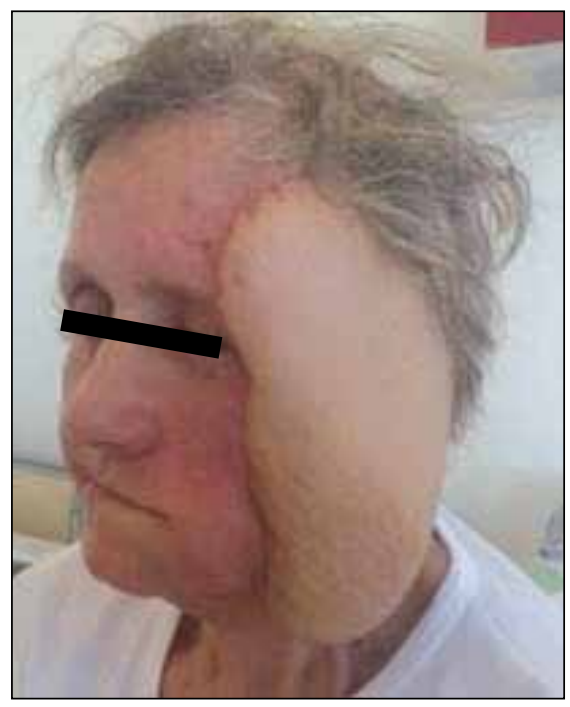

Figure 1: The patient had left facial nerve palsy from the total parotidectomy.

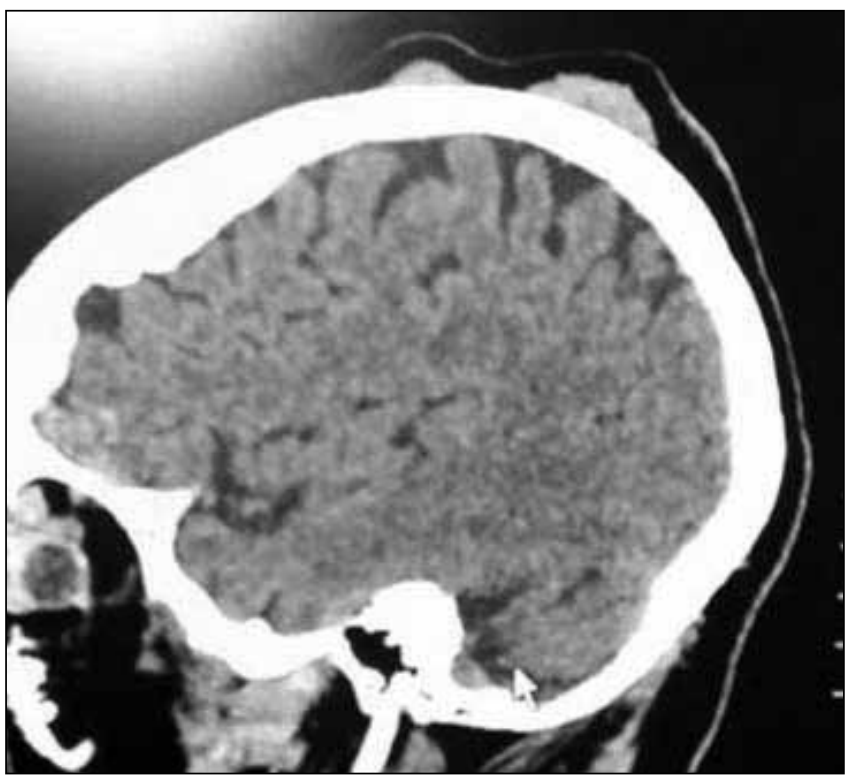

Figure 2: CT demonstrated two adjacent solid lesions located in the subgaleal region.

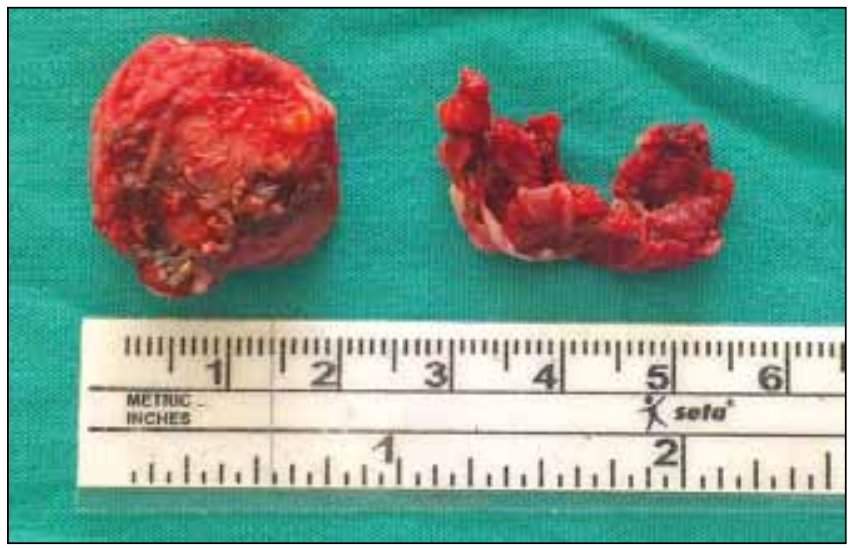

Figure 3: The larger solid lesion was $2.5 \times 2 \times 1,5 \mathrm{~cm}$ in size. prone to recur. BCA of the parotid gland should be classified as a low-grade carcinoma due to their biologic behavior. The prognosis of this tumor could not have been established statistically because of the rarity. The local recurrence rate varies between $28 \%$ and $76 \%$ (6). Metastases have occurred in less than $10 \%$ of patients (1). Due to the rarity of distant metastasis and regional lymph node involvement, long-term outcomes following surgery are favourable $(1,3)$.

Metastasis of parotid carcinomas to the cervical lymph nodes, liver, lungs, orbita and intracranial extension along the perineural invasion of the facial nerve has been described in the literature $(8,10)$. The cranial metastasis of malignant salivary gland tumors is rare and most of the reported cases are from adenocystic carcinoma of the parotid gland (7). As we have seen in literature, our case will provide the first documented BCA of parotid gland metastasizing to the scalp.

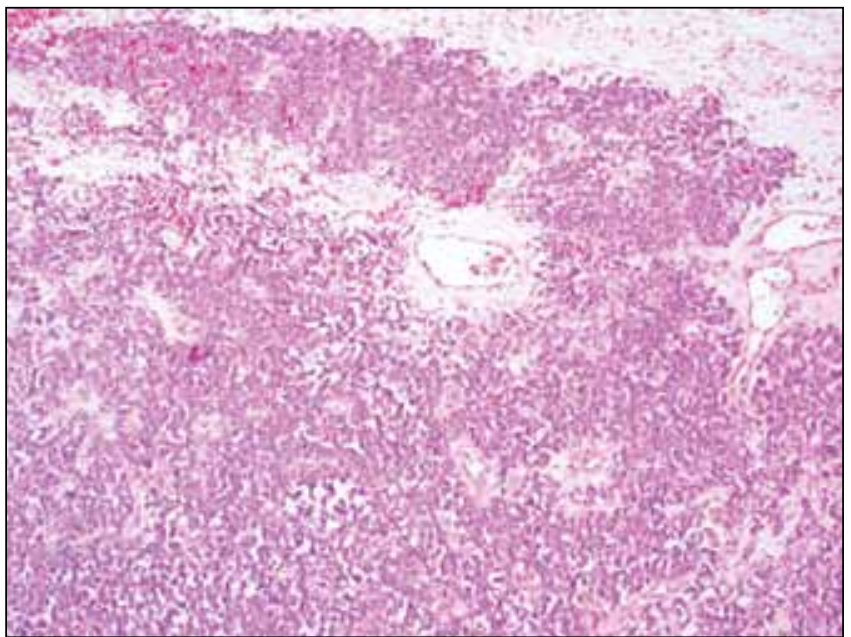

Figure 4: Solid growth pattern in a fibrous stroma, cells with narrow cytoplasm, large nucleus infiltrating the tumor tissue, $\mathrm{HE}$ (x100).

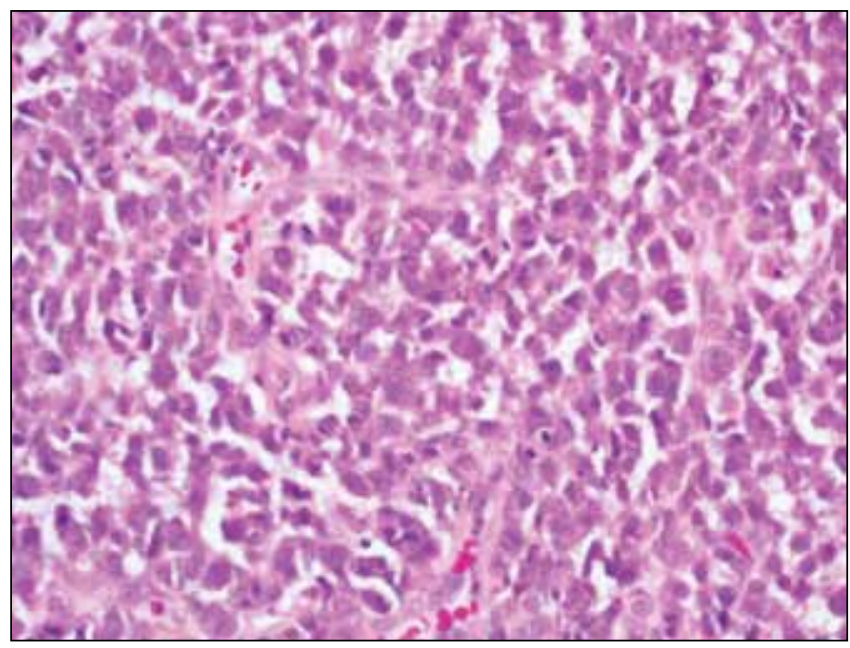

Figure 5: Large magnification: high mitotic activity and nuclear pleomorphism seen in tumor cells, HE (x400). 
The lesions of scalp are more benign than malignant but the exact incidence is unknown (2). As seen in our patient, any history of malignancy further increases the malignancy risk of the scalp or calvarial lesion. Due to the risk of malignancy, we should perform radiological examination before surgery and the biopsy material should be histopathologically examined in scalp lesions. Another issue of note is that scalp metastases are often painful (9). In surgical treatment, resection of the procedure should be gross and neural structures should be protected carefully. Such an approach provides a positive contribution to the patient's prognosis. The frozen samples should be evaluated during the surgical procedure. This is important in terms of guiding the procedure.

\section{REFERENCES}

1. Elvey $\mathrm{MH}$, Aghasi M, Wasrbrout Z, Avisar E: Metastasis of parotid basal cell adenocarcinoma to the hand - a case report. HAND 6: 321-323, 2011

2. Erol FS, Arici L, Kaplan M, Akgun B: 37 olguda skalp ve kalvaryum'un neoplastik lezyonları: Literatür gözden geçirilmesi. Türk Nörosir Derg 19(1): 25-31, 2009

3. Franzen A, Koegel K, Knieriem HJ, Pfaltz M: Basal cell adenocarcinoma of the parotid gland: $A$ rare tumor entity: Case report and review of the literature. HNO 46:821-825, 1998
4. Gok U, Sakallioglu O, Dagli AF: Basal cell adenoma of the parotid gland: Case report. Firat Tıp Dergisi 11: 150-152, 2006

5. Hara H, Oyama T, Saku T: Fine needle aspiration cytology of basal cell adenoma of the salivary gland. Acta Cytol 51: 685-691, 2007

6. Ikeda K, Watanabe M, Oshima T, Nakabayashi S, Kudo T, Sawai T, Takasaka T: A case of basal cell adenocarcinoma of the parotid gland. Tohoku J Exp Med 186:51-59, 1998

7. Lee DK, Chung KW, Baek CH, Jeong HS, Ko YH, Son YI: Basal cell adenoma of the parotid gland: Characteristics of 2-phase helical computed tomography and magnetic resonance imaging. J Comput Assist Tomogr 29(6):884-888, 2005

8. Vidyadhara S, Shetty AP, Rajasekaran S: Widespread metastases from acinic cell carcinoma of parotid gland. Singapore Med J 48(1): e13, 2007

9. Wackym PA, Feverman T, Strasnick B, Calceterrra TC: Reconstruction of massive defects of the scalp, cranium and dura after resection of scalp neoplasms. Head Neck 12: 247-253, 1990

10. Wilson JR, Kumar R, van Hille PT: Cerebellopontine angle metastasis of a parotid mucoepidermoid carcinoma arising from perineural invasion along the facial nerve. $\mathrm{Br} J$ Neurosurg 26(3):417-419, 2012 